\title{
Proposing Electronic Learning Business Model for Students
}

\author{
Hamed esmaeelzadeh ${ }^{1 *}$, Elmira Fateh Dizaji ${ }^{2}$ \\ $1 *$ Department of industrial engineering, Faculty of MBA, \\ College of Engineering Campus 2 University Of TehranTehran ,Iran \\ Email: Hamed.esmaeelzadeh90@gmail.com \\ 2 Department of Business Management ,Faculty of Management, \\ Varamin Branch, Islamic Azad University, Varamin ,Iran
}

\begin{abstract}
Nowadays, education's dependency on the application of technology has been increased. Furthermore, considering the electronic learning business models are increasingly felt. However, no appropriate localized business model in electronic learning has been investigated. The current study aims to propose an electronic learning business model for high school students. To do so, by studying books and previous papers and researches, the dimensions of the model were initially determined based on two theoretical models of Osterwalder (2009) and ATOL electronic learning model in 9 aspects. The statistical population was the managers and teachers of education administration of Tehran Province and the sample size was determined 320 . The researcher made a questionnaire was used to collect the data and after assessing its reliability by convergent method and validity in the combined method, the questionnaire was given to the sample size. The results showed that the final model was confirmed having 9 aspects of the customer department, proposed values, telecommunication channels, communication, return on investment of electronic learning, key sources, key activities, key participations, and cost structure along with 52 indicators. Also, according to the goodness of fit, the model enjoys of adequate goodness of fit.
\end{abstract}

Keywords: Business, Learning, Electronic Learning, Electronic Learning Business Model

\section{Introduction and Theoretical Foundations}

Proper education and its implementation in the educational process is one of the most important aims of each education system so that by its application, the context for the progress of the education system be provided (Cvijovic,2016). The education system is the main and most important system in the education of future generations and students of every society that for the success of the system, various long term, middle term and short term programs are codified (Gulcan, 2015). In recent years, the education's dependency on the application of technology has been increased and one of the most important success indicators is the application of innovation in its specific framework to remain in the competition arena and provide the feedback resulted from that and the available resources (Nor Azlina et al, 2016, Little, 2016). Innovation is specifically involved with technology and related factors. In fact, the evolution of technology-based and existing tools in this field is the basis for the growth and equipping of tools towards progress and updating of related conditions (Sivarajah et al, 2015). The use of technology is not only focused on the commercial and competitive market, but also on scientific advances and achievements such as educational sciences (Garavand, 2016) and it is the underlying factor in predetermined progress even in large sectors such as government functions (Sorn-in et al, 2015). Technology and its application in different parts of work is a key factor in progress and improvement in various indicators (Gotsch, 2014). Accordingly, e-learning is a new topic that is gradually opening its place among educational methods. E-learning is actually education using the computer, multimedia networks, and the Internet that has been facilitated by the increasing growth of information technology. Today, e-learning is considered as the most important factor in the development of information technology, and activists in this field believe that due to the familiarity of technology with this language, this educational system is not limited to any specialty, level, age and special courses. Instructors have always dreamed of using both visual, written, and auditory tools to enhance their education and teaching. The existence of multimedia equipment and the power to use all teaching tools will be the key to the success of this method. This method is effective and efficient for students because it improves the efficiency of education, their educational activities, performance, teaching and classroom behavior of teachers. Because based on the conducted research, it has been concluded that $75 \%$ of learning is done through visual and video aids and by the sense of sight, and only $17 \%$ of learning is done through the sense of hearing and sound devices (Sharifi \& Faghihi,2013). 
Mobile commerce is one of the newest models of e-business and one of the manifestations of the application of information technology that different countries have been able to achieve many benefits by using its benefits in various fields such as health and education (Dargahi and Mohammadzadeh, 2011). Applying electronic measures in the education sector of different countries has many benefits, such as improving the quality of educational services, increasing efficiency, reducing costs, and increasing revenue. The use of electronic work models in the field of education is an example of these measures (Azizi et al., 2013). Many management experts estimate that 53 to 93 percent of e-learning businesses fail in the implementation phase, which is more likely to be the reason for the failure of e-learning businesses than to codify them (Candido and Santos, 2008). Success in implementing an e-learning program requires a proper process of the principles of planning, designing, evaluating and implementing online learning environments. In an e-learning system, not only the learner should be considered, but considering all the stakeholders is important as well. Undoubtedly, the Internet is distributed in an open and flexible environment. But technology alone is not able to create a meaningful educational environment unless education is integrated with different technologies (Rezaei Rad, 2012).

According to studies, different dimensions are important in e-learning business. In King and Boyt's research, the findings show that attention to organizational culture and the development of organizational infrastructure is essential to the support and success of e-learning in organizations. In a study by Ruiz et al., It was found that factors such as more learner control over the content and the use of media types made e-learning very useful and effective. Also, for the success of e-learning, its technical and structural dimensions must be considered. These infrastructures include digital reservoirs or libraries, access to e-learning materials management, and consensus on technical standards (Ruiz et al, 2006). In Fathi \& Ejaregah et al.'s research to measure the effectiveness of virtual training courses, these components including content, learning and teaching activities, website design, organizing feedback training materials, flexibility, workload, assistance, motivation, evaluation methods, and results were considered important and were examined and showed that according to the professors, the effectiveness of the e-learning course was desirable and the students evaluated the effectiveness of this course as average (Fathi and Ejaregah, 2011). In Rezaei Rad's research, the findings showed that the use of the latest facilities and equipment in the field of e-learning, regardless of the factors of success in e-learning, is useless. In this study, the success factors in e-learning were identified, which include: educational content, access to the site, the collaboration of learners, security and website support, the commitment of institute, interactive learning environment, capability and ability of professors and presentation and design (Rezaei Rad, 2012). By investigating the studies conducted on the e-learning business, various indicators and dimensions were important in the field of e-learning business and each of these studies investigated different disciplines of electronic business; however, no localized model in electronic business has been proposed so far for the high school students and by understanding this research gap, the study in a case study is of necessity and importance to determine the aspects of e-learning business model indicators for the high school students. 


\section{Research Background}

The research background has been represented in Table1.

Table1. Research Background

\begin{tabular}{|c|c|c|c|}
\hline \multicolumn{4}{|r|}{ Foreign research background } \\
\hline Row & Researchers & Year & Research topic and findings \\
\hline 1 & $\begin{array}{l}\text { Trajkovsi et } \\
\text { al }\end{array}$ & 2016 & $\begin{array}{l}\text { Research entitled a change from the e-learning method to portable learning, } \\
\text { they conducted a study on the present and future issues. This research } \\
\text { considers the portable learning in the atmosphere of modern learning } \\
\text { methods. There are three main groups of challenges including technology, } \\
\text { development and education that are defined in the change from e-learning } \\
\text { to portable learning. }\end{array}$ \\
\hline 2 & Alfervicet al & 2016 & $\begin{array}{l}\text { In research entitled the E-learning process management and the } \\
\text { performance of e-learning: findings of an experimental study in Europe, } \\
\text { they designed and estimated a comprehensive model for e-learning } \\
\text { processes management, e-learning and its various aspects. The results of } \\
\text { the study emphasized on an obvious relationship between planning and e- } \\
\text { learning process control and its success. }\end{array}$ \\
\hline 3 & Siang & 2015 & $\begin{array}{l}\text { They implemented research entitled the vision of users from the learning } \\
\text { management system: experimental evidence based on the e-learning } \\
\text { acceptance model. The research results showed that there is a significant } \\
\text { relationship between the understanding of ease of use and understanding of } \\
\text { the usefulness of e-learning and the attitude. }\end{array}$ \\
\hline 4 & Ashibly & 2014 & $\begin{array}{l}\text { A study entitled Experimental study of the factors affecting the tendency } \\
\text { of employees to e-learning developed the technology acceptance model } \\
\text { among the employees of service companies. The results showed that the } \\
\text { efficiency and quality of the system have a significant effect on the } \\
\text { intention to use, easy to understand and understanding the usefulness, and } \\
\text { understanding of ease of use and usefulness have a significant effect on } \\
\text { employee tendency to e-learning. }\end{array}$ \\
\hline 5 & $\begin{array}{l}\text { Gholami \& } \\
\text { Norouzi }\end{array}$ & 2017 & $\begin{array}{l}\text { They conducted a study entitled "Surveying and Comparing the } \\
\text { Satisfaction of the Employees of the National Oil Company with e-learning } \\
\text { and face-to-face training courses. The employees of the National Oil } \\
\text { Company were considered the statistical population. The statistical sample } \\
\text { was } 108 \text { employees who participated in virtual training courses in } 2015 \text {. } \\
\text { The test results showed that there is a significant difference between } \\
\text { satisfaction with virtual and face-to-face learning. }\end{array}$ \\
\hline 6 & $\begin{array}{l}\text { Bagheri Majd } \\
\& \text { Sedghi } \\
\text { Boukani }\end{array}$ & 2017 & $\begin{array}{l}\text { A study entitled Designing an e-learning preparation model in the Islamic } \\
\text { Azad University's educational system, Mahabad Branch. The results were } \\
\text { significant in the e-learning preparation section according to the T-test and } \\
\text { in the e-learning barriers section according to the analysis of the } \\
\text { exploratory factor (Varimax rotation), pedagogy- behavioral, managerial- } \\
\text { structural, cultural-economic contextual- technological and Individual - } \\
\text { Professional factors were identified. Also, in the interview section, } 59 \\
\text { initial conceptual propositions, } 5 \text { main category propositions and } 14 \\
\text { subcategories have been identified in three sections: causal, contextual and } \\
\text { environmental. }\end{array}$ \\
\hline 7 & Seyf \& Fathi & 2017 & $\begin{array}{l}\text { They conducted research entitled the causal model of acceptance and } \\
\text { application of e-learning in the employees: role of the proportion of } \\
\text { technology-job, self-efficiency and mental norm. the results showed that } \\
\text { the variables of the fitness of technology-profession, mental norm, and self- } \\
\text { efficiency of the computer, directly and indirectly, have a significant } \\
\text { impact on the variable of tendency and application of virtual learning } \\
\text { among the employees through mediating variables such as the perceived } \\
\text { ease of use and the perceived usefulness. }\end{array}$ \\
\hline
\end{tabular}




\section{Research Method}

This research is applied in terms of objective and is descriptive and survey in terms of method and is confirmatory factor analysis.

The statistical population of the current research includes teachers and managers of the Education Administration of Tehran Province. By considering the cluster method, 4 districts of Tehran are considered as a statistical population of the current research which is 1930 in total.

In this research, the cluster sampling method was used to select the sample. In this method, the statistical population was classified into 30 clusters based on 30 districts of Tehran and then, based on the random sampling method, 4 clusters are selected among 30 clusters (1,3,4,12 districts) for sampling. The sample size was obtained using Cochran's formula presented in equation 1 which is 320 . The share of managers and teachers of district 1 of Tehran Province in the sample is 98. The share of teachers and managers of district 3 of Tehran Province is 75. The share of teachers and managers of district 4 of Tehran Province in the sample is 63 and the share of teachers and managers of district 12 of Tehran Province is 84 .

$$
n=\frac{\frac{t^{2} p q}{d^{2}}}{1+\frac{1}{N}\left(\frac{t^{2} p q}{d^{2}}-1\right)}
$$

\section{Equation 1}

$$
\begin{array}{ll}
\mathrm{N}=1930 & \text { (statistical population) } \\
\mathrm{P}=0.5 & \text { the possibility of having the considered feature } \\
\mathrm{q}=0.5 & \text { the possibility of lack of the considered feature } \\
\mathrm{d}=0.05 & \text { desired possible accuracy (half of the confidence distance) } \\
\mathrm{t}=1.96 & \text { confidence coefficient of } 95 \%
\end{array}
$$

To collect the data from the sample and to answer the research questions, a questionnaire based on the theoretical model of Alexander Osterwalder (2009) and e-electronic model of ATOL (2006) was used. This questionnaire has 9 aspects and 52 questions and psychometrics confirmed its content validity and reliability.

\section{Findings}

Descriptive studies showed that $58 \%$ of the research sample is male and $42 \%$ is female. $90 \%$ are married and $94 \%$ have bachelor degree and higher and $6 \%$ have associate degree.

In the first part of the research, the normalization of the obtained data was investigated and represented in Table 2.

\begin{tabular}{|l|l|l|l|l|}
\hline Variables & Data number & $\begin{array}{l}\text { Statistics of } \\
\text { Kolmogorov } \\
\text { Smirnov }\end{array}$ & -value & $\begin{array}{l}\text { Results (normal- } \\
\text { abnormal } \\
\text { distribution })\end{array}$ \\
\hline Customer department aspect & 320 & 2.434 & 0.135 & Normal \\
\hline Proposed value aspect & 320 & 2.661 & 0.098 & Normal \\
\hline Channel aspect & 320 & 2.819 & 0.113 & Normal \\
\hline Communication aspect & 320 & 2.510 & 0.070 & Normal \\
\hline Capital return aspect & 320 & 1.984 & 0.087 & Normal \\
\hline Key resources aspect & 320 & 2.445 & 0.421 & Normal \\
\hline Key activities aspect & 320 & 2.741 & 0.096 & Normal \\
\hline Key participation aspect & 320 & 2.996 & 0.123 & Normal \\
\hline Cost structure aspect & 320 & 1.999 & 0.099 & Normal \\
\hline
\end{tabular}

Considering the significance obtained higher than 0.05 , conducting the parametric test for all the variables is permitted.

To confirm the obtained factor structure and power and significance test of each one of the aspects in the e-learning business model scale, the confirmatory factor analysis was done and represented in Graphs 1 and 2. 


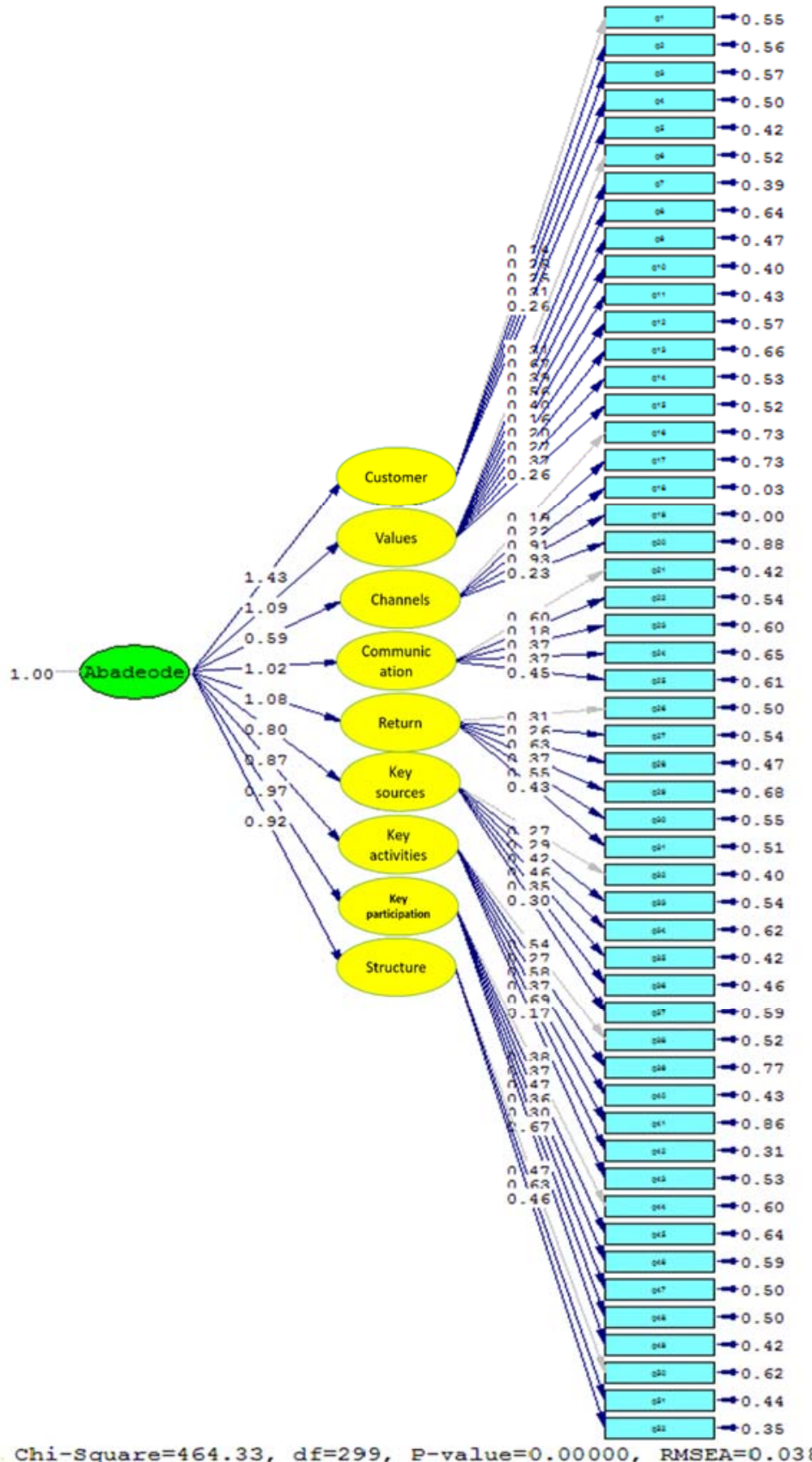

Figure 1. confirmatory factor analysis of level 2. Confirming the aspects and indicators of e-learning business model based on factor load 


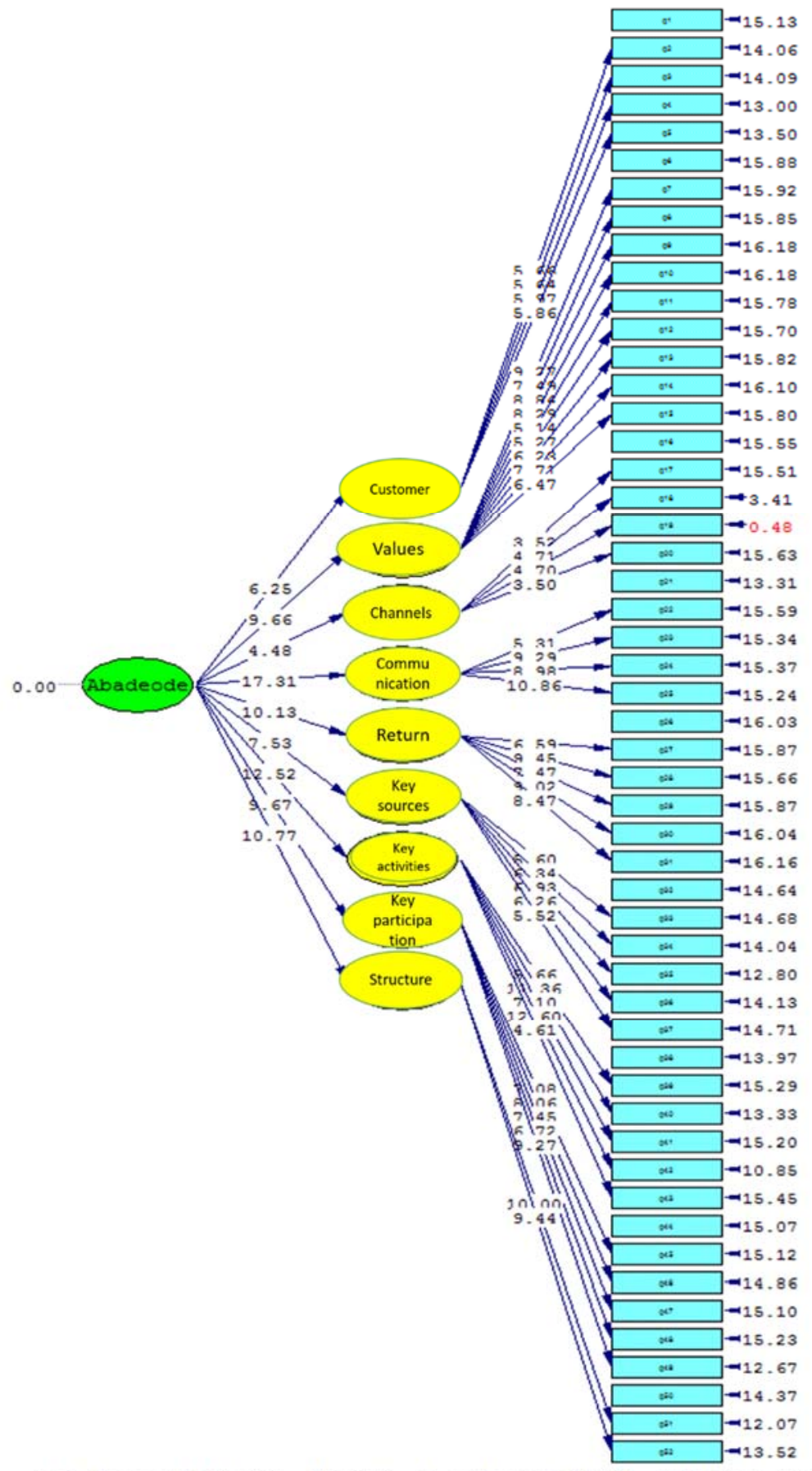

Chi-Square $=464.33, d f=299, \quad p-v a l u e=0.00000$, RMSEA $=0.038$

Figure 2. confirmatory factor analysis in level 2. Confirming the aspect and indicators of the e-learning business model based on significance coefficient 
In the following, the impact of endogenous latent variables on the observed variable is investigated in Table 2.

Table 2. the impact of endogenous latent variables on the observed variables

\section{،Y(yגLAMBDA-Y(}

\begin{tabular}{|c|c|c|c|c|}
\hline Parameter, items and factors & $\begin{array}{l}\text { Estimation of } \\
\mathrm{b} \text { parameter }\end{array}$ & $\begin{array}{c}\text { Standardized } \\
\text { parameter }\end{array}$ & $\mathrm{T}$ & Result \\
\hline \multicolumn{5}{|c|}{ Customer } \\
\hline Instructors and professional teachers & 0.14 & 0.32 & - & Confirmed \\
\hline Students & 0.25 & 0.91 & 5.66 & Confirmed \\
\hline Providing education services & 0.25 & 0.98 & 5.64 & Confirmed \\
\hline Consolers & 0.31 & 0.61 & 5.97 & Confirmed \\
\hline Support team & 0.31 & 0.61 & 5.97 & Confirmed \\
\hline \multicolumn{5}{|c|}{ Proposed value } \\
\hline Novelty of the educational content & 0.34 & 0.39 & - & Confirmed \\
\hline Higher quality of educational materials & 0.67 & 0.78 & 9.27 & Confirmed \\
\hline $\begin{array}{l}\text { Considering the educational needs of } \\
\text { students }\end{array}$ & 0.39 & 0.43 & 9.49 & Confirmed \\
\hline Help to enhance learning & 0.56 & 0.63 & 8.84 & Confirmed \\
\hline User friendly design & 0.40 & 0.53 & 8.29 & Confirmed \\
\hline Using a special brand in providing service & 0.16 & 0.24 & 5.14 & Confirmed \\
\hline Lower education costs & 0.20 & 0.25 & 5.27 & Confirmed \\
\hline $\begin{array}{c}\text { Guarantee to reduce the risk of losing } \\
\text { services }\end{array}$ & 0.27 & 0.32 & 6.23 & Confirmed \\
\hline Quick access & 0.37 & 0.45 & 7.71 & Confirmed \\
\hline Ease of use & 0.26 & 0.334 & 6.47 & Confirmed \\
\hline \multicolumn{5}{|c|}{ Channel } \\
\hline $\begin{array}{l}\text { Holding different virtual learning classes } \\
\text { based on the users' needs }\end{array}$ & 0.19 & 0.24 & - & Confirmed \\
\hline Activity of suggestions and critics system & 0.19 & 0.24 & - & Confirmed \\
\hline $\begin{array}{l}\text { Virtual sale of educational service and } \\
\text { products }\end{array}$ & 0.91 & 0.98 & 4.71 & Confirmed \\
\hline Virtual distribution of educational services & 0.93 & 0.10 & 4.70 & Confirmed \\
\hline $\begin{array}{l}\text { Receiving orders and delivery of products } \\
\text { and services to the users }\end{array}$ & 0.23 & 0.23 & 3.50 & Confirmed \\
\hline \multicolumn{5}{|c|}{ Communication } \\
\hline $\begin{array}{c}\text { The possibility of online communication } \\
\text { between students and teachers }\end{array}$ & 0.60 & 0.68 & - & Confirmed \\
\hline $\begin{array}{l}\text { The relationship between users and } \\
\text { company representative }\end{array}$ & 0.18 & 0.24 & 5.31 & Confirmed \\
\hline Self-service education & 0.37 & 0.43 & 9.29 & Confirmed \\
\hline Using virtual networks and communities & 0.37 & 0.41 & 8.98 & Confirmed \\
\hline $\begin{array}{c}\text { The ability to facilitate the learners' } \\
\text { interaction with content }\end{array}$ & 0.45 & 0.50 & 10.86 & Confirmed \\
\hline \multicolumn{5}{|c|}{ Capital return of e-learning } \\
\hline $\begin{array}{c}\text { The membership fee of the students in the } \\
\text { designed platforms to use services }\end{array}$ & 0.31 & 0.39 & - & Confirmed \\
\hline $\begin{array}{c}\text { The membership fee of teachers to offer } \\
\text { their teaching and advertising their } \\
\text { performance }\end{array}$ & 0.26 & 0.33 & 6.59 & Confirmed \\
\hline $\begin{array}{c}\text { The copyright of the designed CDs for the } \\
\text { education }\end{array}$ & 0.63 & 0.67 & 9.45 & Confirmed \\
\hline
\end{tabular}




\begin{tabular}{|c|c|c|c|c|}
\hline $\begin{array}{l}\text { Advertisement after having a great } \\
\text { number of customers }\end{array}$ & 0.37 & 0.40 & 7.47 & Confirmed \\
\hline $\begin{array}{c}\text { Constant access to the services with } \\
\text { membership }\end{array}$ & 0.55 & 0.59 & 9.02 & Confirmed \\
\hline $\begin{array}{l}\text { Permitting the users in return of paying } \\
\text { the copyright }\end{array}$ & 0.43 & 0.51 & 8.47 & Confirmed \\
\hline \multicolumn{5}{|c|}{ Key resources } \\
\hline Physical assets & 0.27 & 0.40 & - & Confirmed \\
\hline Hardware facilities & 0.29 & 0.38 & 6.60 & Confirmed \\
\hline Strong counseling team & 0.42 & 0.47 & 6.34 & Confirmed \\
\hline Experienced and elite training team & 0.46 & 0.58 & 6.93 & Confirmed \\
\hline Financial credits & 0.35 & 0.46 & 6.29 & Confirmed \\
\hline Physical resources & 0.30 & 0.37 & 5.52 & Confirmed \\
\hline \multicolumn{5}{|c|}{ Key activities } \\
\hline Educational activities & 0.54 & 0.60 & - & Confirmed \\
\hline Advertisement activities & 0.27 & 0.29 & 6.66 & Confirmed \\
\hline Proposing annual reports & 0.58 & 0.66 & 11.36 & Confirmed \\
\hline Holding conferences & 0.37 & 0.37 & 7.10 & Confirmed \\
\hline $\begin{array}{l}\text { Designing comprehensive tools to provide } \\
\text { educational service }\end{array}$ & 0.69 & 0.78 & 12.60 & Confirmed \\
\hline $\begin{array}{l}\text { Proper planning to benefit from the } \\
\text { teachers to record the teaching }\end{array}$ & 0.17 & 0.23 & 4.61 & Confirmed \\
\hline \multicolumn{5}{|c|}{ Key Participation } \\
\hline $\begin{array}{l}\text { Providing produced programs and } \\
\text { software for the learning companies }\end{array}$ & 0.38 & 0.44 & - & Confirmed \\
\hline $\begin{array}{c}\text { Education administration support from the } \\
\text { e-learning }\end{array}$ & 0.37 & 0.42 & 6.08 & Confirmed \\
\hline Having rules and related support policies & 0.47 & 0.53 & 8.06 & Confirmed \\
\hline Survey and experts participation & 0.36 & 0.46 & 7.45 & Confirmed \\
\hline $\begin{array}{l}\text { Programming and designing products and } \\
\text { graphic parts for specialized companies }\end{array}$ & 0.30 & 0.39 & 6.72 & Confirmed \\
\hline $\begin{array}{l}\text { Cooperation or partnership with schools } \\
\text { and institutes }\end{array}$ & 0.67 & 0.72 & 9.27 & Confirmed \\
\hline \multicolumn{5}{|c|}{ Capital structure } \\
\hline $\begin{array}{l}\text { Human resource costs (managers, } \\
\text { supporter, and technical sectors payments) }\end{array}$ & 0.47 & 0.51 & - & Confirmed \\
\hline $\begin{array}{l}\text { The cost of providing infrastructure (the } \\
\text { required costs for the establishment of } \\
\text { software and hardware layers) }\end{array}$ & 0.63 & 0.69 & 10.00 & Confirmed \\
\hline $\begin{array}{l}\text { Other costs (maintenance, development, } \\
\text { advertisement and branding) }\end{array}$ & 0.46 & 0.61 & 9.44 & Confirmed \\
\hline
\end{tabular}

Questions 1,6,16,21,26,32,38,44, and 50 are considered fixed scale variable and the t-values is not reported. According to the information presented in Table2, the estimated coefficients of all the paths are significant. The values of the standardized parameter for each one of the observed variables indicate the power of the factor load on the latent variable and its significance by showing its t-value higher than 1.97. in the flowing, the impact of the latent exogenous variables (aspects and indicators of the e-learning business model) on the latent endogenous variables (customer, the proposed value, channel, communication, capital return, key resources, key activities, key participation, and cost structure) is investigated. Table 3 shows the impact of all latent exogenous variables $(\mathrm{KSI}, \xi)$ on the latent endogenous variables (ETA, १). 
Table3. the total impact of all the latent exogenous variables (KSI, $\xi$ ) on the latent endogenous variables (ETA, $\eta$ ).

\begin{tabular}{|c|c|c|c|c|}
\hline Dimensions & $\begin{array}{c}\text { Parameter } \\
\text { estimation }\end{array}$ & $\begin{array}{c}\text { B Standardized } \\
\text { parameter }\end{array}$ & $\begin{array}{c}\text { T significance } \\
\text { coefficient }\end{array}$ & Result \\
\hline \multicolumn{5}{|c|}{ Dimensions approved in e-learning business model } \\
\hline Customer & 1.43 & 0.83 & 6.25 & Confirmed \\
\hline Proposed value & 1.09 & 1.09 & 9.66 & Confirmed \\
\hline Channel aspect & 0.59 & 0.61 & 4.48 & Confirmed \\
\hline Communication & 1.02 & 1.03 & 17.31 & Confirmed \\
\hline Capital return & 1.08 & 1.11 & 10.13 & Confirmed \\
\hline Key resources & 0.80 & 0.79 & 7.53 & Confirmed \\
\hline Key activities & 0.87 & 0.87 & 12.52 & Confirmed \\
\hline Key participation & 0.97 & 0.96 & 9.67 & Confirmed \\
\hline Cost structure & 0.92 & 0.92 & 10.77 & Confirmed \\
\hline
\end{tabular}

Since the t-value of the significant coefficient for all the aspects studied in the tested model is higher than 1.96, with $95 \%$ confidence level, it can be said that all the dimensions and indicators examined are confirmed and in the e-learning business model, all the dimensions have significant importance and are confirmed. One the one hand, the coefficient of the standardized parameter indicates the impact of each dimension in the examined model. According to this coefficient, it can be mentioned that customer, proposed value, channel, communication, capital return, key resources, key activities, key participation, and the cost structure dimensions as $0.83,1.09,0.61,1.03$, $1.11,0.79,0.87,0.96$, and 0.92 , respectively, explain the abovementioned model.

To investigate the final goodness of fit of the e-learning business model for the high school students, the GFI coefficient was used. Table 4 shows the indicators of goodness of fit of the research model.

Table 4. research model indicators of goodness of fit

\begin{tabular}{|c|c|}
\hline Statistics & Value \\
\hline K-square absolute fit index (X2) & 169.31 \\
\hline Degree of freedom & 194 \\
\hline Absolute fit index/ degree of freedom & 0.87 \\
\hline Root Mean Square Error of Approximation (RMSEA) & 0.018 \\
\hline p-value (Significance level) & 0.001 \\
\hline The goodness of Fit Index (GIF) & 1.01 \\
\hline Adjusted Goodness of Fit Index (AGIF) & 0.99 \\
\hline
\end{tabular}

According to the results obtained from the structural equations model, the value of X2/DF was calculated 0.87 and considering that the obtained value is lower than 3 , it indicates that the goodness of fit of the model is appropriate. Furthermore, RMSEA must be less than 0.08 which is 0.059 in the given model. GFI and AGFI are 1.01 and 0.99 , respectively which must be more than 0.80 . Therefore, 9 the e-learning business model with 9 dimensions is confirmed and the model has a good fit.

\section{Discussion and Conclusion}

Education is a key element in building and shaping progress in a society and nation, and improving its structure and functionalization from different angles is the most important structural goal of an educational system (Vogel, 2015). Accordingly, this study examined the e-learning business model in students. The results of the present study showed that the final model with nine dimensions: customer, proposed value, channel, communication, capital return, key resources, key activities, key participation, and cost structure and 52 items were confirmed and the fit of the model was assessed as appropriate. The literature review shows the confirmation of the investigated dimensions and indices in the final e-learning business model for high school students. The results of the current research are consistent with the studies conducted by Fathi \& Ejaregah et al (2011) in which, the evaluation of the e-learning components such as content, learning and teaching activities, page design, organization of the educational materials, feedback, flexibility, workload, assistance, motivation, evaluation methods are considered important. Furthermore, these results are consistent with the results of the study conducted by Rezairad (2012) in which, the identification of the factors related to the success in the implementation of the e-learning program in the higher education showed that the dimensions of educational content, access to the site, cooperation and participation of the learner, security and support of the website, institute's commitment, interactive learning, capability and ability of the teachers and proposing and design are significantly important in the e-learning. 
Considering the research results, the customers of the company are specifically students and according to the official statistics of the Sanjesh Organization, annually, 1 million students compete every year to enter universities. The second dimension of the e-learning business model for the high school students was the proposed values including the reduction in the education costs, ease of use, and access to e-learning. The third dimension of the elearning business model was the communication channels between the company and the students and the most important method is the information exchange environment. Currently, according to the official statistics of the education administration, $90 \%$ of the students in the big cities use the internet. This number is increasing in small towns. In the next part of this mode, the communication methods with the customer are discussed and according to the collected information through the interview with the principles and the experts, the best method of communication with the students in e-learning was joint creation and then the communities were analyzed. The joint creation means that the students are used in the development of the tools and to be able to create a proper communication in the platform environment so that the double attractiveness are provided for the high school students. Furthermore, virtual networks and communities are the very appropriate path according to the great use of the internet. Based on the data obtained from the interview as well as Osterwalder's theories, among the types of monetization in the e-learning of students, the membership fee in the site or the produced programs and advertising are considered among the most important income sources of the company. The key sources of the business model include physical, spiritual, human, and financial sources. The main difference in this part of the study is the spiritual and human sources. In this study, all the expert teachers, designers, and programmers are considered to execute this model and presenting the model is considered in such a way that all the students around the country, students in the remote and poor regions, be able to pay the fees to use this education; because the main goal is to have educational justice in today's competitive environment in the pre-university period. Among the key activities, it is clear that the successful implementation of this business model requires activities such as proper design, perfect programming, proper schedule for teacher's teaching and establishment of communication and the method of informing the students about the tools and the produced content. In the next part, the key participants of the business model were discussed. In many of the companies, it is required to do outsourcing and designs or any kind of output considered by the company must be created by the specialized companies in that area. In the e-learning model of students, the outsourcing is also conducted in the programming and graphic design so that by using the expertise and experiment of the specialized companies in this area, the quality of the programming and designing be higher than when the company does it through less experience. In the last part of the research, the cost structure was investigated which includes the fixed costs such as the rent cost of the place, the hardware required for teaching and recording the images, the payment of the programmers along with the variable costs for teachers and the number of teaching hours, the advertising costs and so on are investigated based on the costs in 2018 in details. In conclusion, according to the obtained results, the designed model is an efficient tool in providing an e-learning business model for students.

\section{References}

[1] Azizi, Nematollah, Shahmohammadi, Anvar and Naghdi, Hadi (2013). Obstacles to the implementation of distance education and identification of solutions for its optimal implementation: A reflection on the viewpoints of managers and teachers of secondary and secondary schools, scientific research journal of educational technology, No.4, Vol.3, 114-130 (In Persian)

[2] Cvijovic, M., Höfer, T., Aćimović, J., Alberghina, L., Almaas, E., Besozzi, D. \& De Atauri, P. (2016). Strategies for structuring interdisciplinary education in Systems Biology: an European perspective. NPJ systems biology and applications, 2, 16011.

[3] Cândido, C. J., \& Santos, S. P. (2015). Strategy implementation: What is the failure rate? Journal of Management \& Organization, 21(2), 237-262.Garavand, A., Mohseni, M., Asadi, H., Etemadi, M., Moradi-Joo, M., \& Moosavi, A. (2016). Factors influencing the adoption of health information technologies: a systematic review. Electronic physician, 8(8), 2713.

[4] Fathi Vajarkhah, Kourosh, Pardakhtchi, Mohammad Hassan, Rabiei, Mahdi (2011). Evaluating the Effectiveness of Virtual Education Courses in Iran's Higher Education System (Case Study: Ferdowsi University of Mashhad), No.4, Vol. 4, 6-20 (In Persian)

[5] Gotsch, M., \& Hipp, C. (2014). Using trademarks to measure innovation in knowledge-intensive business services. Technology Innovation Management Review, 4(5).

[6] Gülcan, N. Y. (2015). Discussing the importance of teaching ethics in education. Procedia-Social and Behavioral Sciences, 174, 26222625.

[7] Sharifi, Maryam and Faqihi, Alireza (2017). Evaluation of e-learning design in high school girls in Arak district from the viewpoint of teachers, administrators and students and its improvement methods, Quarterly e-learning, No.2, Vol.10 (In Persian)

[8] Sorn-In, K., Tuamsuk, K., \& Chaopanon, W. (2015). Factors affecting the development of e-government using a citizen-centric approach. Journal of Science \& Technology Policy Management, 6(3), 206-222.

[9] Little, L. M., Gooty, J., \& Williams, M. (2016). The role of leader emotion management in leader-member exchange and follower outcomes. The Leadership Quarterly, 27(1), 85-97.

[10] NorAzlina, A.b., Aliza ,R. (2016). Entrepreneurial Orientation, Strategic Management Accounting Practices, Innovation, and Firm Performance: Craft Industry Perspective. Proceedings of the ASEAN Entrepreneurship Conference 5,179-191.

[11] Reaei Rad, M ojaba (2012). Identifying Success Factors in Implementation of Electrical Training Program in Higher Education, Research in Curriculum Planning, No.2, Vol.9, 106-115 (In Persian)

[12] Vogel, F., Kollar, I., Ufer, S., Reichersdorfer, E., Reiss, K., \& Fischer, F. (2016). Developing argumentation skills in mathematics through computer-supported collaborative learning: the role of transactivity. Instructional Science, 44(5), 477-500. 